\title{
I ．膵癌
}

\section{3. 膵癌の鑑別診断}

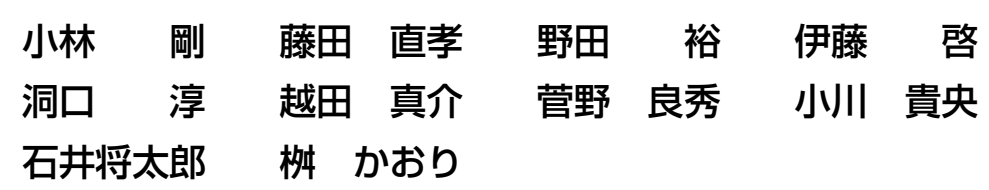

要旨

膵癌に対する手術適応の判定には, MDCTによる診断が必須である. 切除不能で化学療法の適応となる 例や，画像にて質的診断が困難な場合にはEUS-FNAが有用である.MRCPは膵癌との関連が問題となって いる, 小囊胞や分枝の拡張の拾い上げに有用で, また, IPMNの経過観察時, 由来浸潤癌や併存癌の検出に は拡散強調画像の併用が役立つ. 膵癌と炎症性腫瘤の鑑別はERCP, EUSによる腫瘤像, 胆管像, 膵管像の 各々の特徵を理解することが重要である. ERCPは微細な膵管の変化を描出可能で, さらに膵液細胞診から 上皮内癌や小膵癌の発見に期待が寄せられる。また，造影剂を用いた超音波による新たな血流評価も試み られている.

〔日内会誌 101：17～28，2012〕

Key words pancreatic cancer, autoimmune pancreatitis, mass-forming pancreatitis, contrast-enhanced colorDoppler EUS

はじめに

通常の浸潤性膵管癌（膵癌）と鑑別を要する 充実性腫瘍には, 転移性膵癌, 神経内分泌腫瘍 (P-NET), solid pseudopapillary tumor(SPT), その他まれに非上皮性の筋原性, 神経原性腫瘍 などが挙げられる。これらは画像診断によって 鑑別可能なことが多い. 本稿では通常型膵癌の 鑑別について, 膵癌診療ガイドラインに示され
ている各検査の意義, 画像による小膵癌の描出, 膵癌と炎症性腫瘤との鑑別, そして topics と順次 述べて行きたい。 なお, 膵癌の中には非典型的 な形態を示す退形成性膵癌や腺扁平上皮癌, 腺 房細胞癌などがあるが特殊例としてここでは割 愛する.

仙台市医療センター仙台オープン病院消化器内科

Pancreatic Tumor : Progress in Diagnosis and Treatment. Topics : I. Pancreatic carcinoma ; 3. Differential diagnosis of pancreatic cancer.

Go Kobayashi, Naotaka Fujita, Yutaka Noda, Kei Ito, Jun Horaguchi, Sinsuke Koshita, Yoshihide Kanno, Takahisa Ogawa, Syotaro Ishii and Kaori Masu : Department of Gastroenterology, Sendai City Medical Center, Japan. 


\section{1. 膵癌診療ガイドラインからみた各種検 査法の位置づけ}

日本膵臓学会による膵癌診療ガイドライン $(2009 \text { 年版 })^{1)}$ では, 膵癌を疑った際に次に行う各 検査の位置づけを述べており，下記に簡略化し て列記する．推奨度などの詳細は医療情報サー ビスMinds（http://minds.jcqhc.or.jp/stc）で公 開されており参照いただきたい.

・US (ultrasonography)：侵襲性が少なく最初 に行うべき.

- 造影CT (computed tomography)：血行動態 の把握から, 質的診断には欠かせない.

・造影US：小病変の描出に有利.

- ERCP (endoscopic retrograde cholangiopancreatography）：ほとんどの膵癌では膵管像に変 化がみられる。

- MRCP (magnetic resonance cholangiopancreatography）：低侵襲性でERCPの診断能と差 がない.

• EUS(endoscopic ultrasonography)：膵癌の診 断能は高いがCTを凌駕しない.

- PET (positron emission tomography) : 腫瘍 径が $2 \mathrm{~cm}$ を超えると良悪性の鑑別診断に有用.

- EUS-FNA (endoscopic ultrasound-guided fine needle aspiration）：各種画像検査により膵腫瘤 の確定診断がつかない症例に対して治療開始前 に行うのが望ましい.

・ERCP下膵液細胞診：評価はまだ確定していな い.

画像診断として最初に導入されるUSには, 膵 尾部, 銁状突起部, そして膵外発育型の癌など の盲点がある．部位や施行者の技量に左右され ないCTは客観性の高い画像が得られ, 汎用性が 高い. multidetector row CT (MDCT)によるdynamicな撮影は, 膵周囲動脈, 門脈系静脈, 膵周 囲神経叢などの局所浸潤やリンパ節転移の診断
に有用である，そのため膵癌の手術適応の判定 に必須であり，適応がないと判定されればさら なる画像検査は不要となり, 精査の負担を回避 できる.ガイドラインにおいては明日への提言 として, US, CTで診断困難な場合には, 専門施 設での細胞診, 組織診の施行を勧めている。す なわち, 発見される膵癌はいまだに $2 \mathrm{~cm}$ 以上の ものが多く, それらの大部分はMDCTによる質 的診断と進展度診断で十分と言える.

一方, 小さい膵癌の検出には解像度からも超 音波内視鏡 (endoscopic ultrasonography:EUS) が有用で, 手術適応となることの多い小膵癌の 存在診断, 進展度診断に重要な役割を果たす.

近年, 膵の小囊胞や分枝の拡張と膵癌との関 連が指摘され, 小膵癌の拾い上げにおける形態 的な手がかりとして注目されている.USに加え 磁気共鳴胆管膵管撮影 (magnetic resonance cholangio-pancreatography：MRCP）の普及と ともに，膵の囊胞性変化に遭遇する頻度が高く なっている. 同様にMRCPでの描出が有用な膵管 内乳頭粘液性腫瘍 (intraductal papillary mucinous neoplasms : IPMN)では, 浸潤癌への進行 以外にも併存癌の発生が問題となっている2). MRCP施行時に拡散強調画像 (diffusion image) も得ることは充実性腫瘤の発見に役立つ.

一方, MRCPで単純に主膵管狭窄像が描出され ても, 空間分解能が低いため膵管狭細像や圧排 性変化などとの鑑別が難しいことが多い.すな わち, 主膵管狭窄を示す腫瘤形成性膵炎, 限局 性自己免疫性膵炎 (AIP) や, 膵癌と鑑別を要す るP-NET, SPT, 漿液性囊胞腺腫 (serous cystadenoma：SCN）による主膵管狭窄の診断は, 本邦 で以前から報告されている通り, ERCPで微細な 膵管の変化を読影することが重要である．さら にERCPは, 膵液を採取し細胞診や分子生物学的 手法を加えることにより，上皮内癌や小膵癌の 発見に大きな役割を果たすものと期待が寄せら れている.PET-CTは腫瘤の質的診断と共に全身 
表 1. 各種画像診断による小膵癌の描出能の比較

\begin{tabular}{lclrrll}
\hline Author & $\begin{array}{c}\text { No. of } \\
\text { patients }\end{array}$ & Size $(\mathrm{cm})$ & US & EUS & CT & MRI (\%) \\
\hline Rosch & 27 & $</=3.0$ & 50 & 100 & 55 \\
Yasuda & 5 & $<2.0$ & 40 & 100 & 20 \\
Pallazo & 7 & $</=2.5$ & 14 & 100 & 14 & \\
Muller & 10 & $<2.0$ & & 90 & 40 & 33 \\
Furukawa & 31 & $<2.0$ & 65 & 74 & 65 \\
Ariyama & 25 & $<2.0$ & 75 & 100 & 85 \\
Legmann & 6 & $</=1.5$ & & 100 & 67 (Dual-phase CT) \\
Kobayashi & 18 & $<2.0$ (histological) & 61 & 94 & 41 \\
& & & & & 67 (MDCT) & \\
\hline
\end{tabular}

(文献 4 より引用)

の情報が得られるため, 始めに遠隔転移を否定 したい時や, 術後再発の判定に向いている.

以上のような膵癌診断の要点と問題点を踏ま え, 小膵癌の画像診断, 腫瘤形成性膵炎, 限局 性AIPとの鑑別診断について述べる.

\section{2. 小膵癌の画像診断の意義}

\section{1）小膵癌の頻度と予後}

膵癌は $2 \mathrm{~cm}$ 以下（TS1）の小さい膵癌であっ ても，腫瘤を形成してしまえば組織学的に脈管 浸潤や神経浸潤を伴っていることが多い．その ため小さい膵癌でも上皮内癌 (CIS, PanIN-3)で ない限り早期癌とは言えない.しかし実際に小 さい膵癌の切除率は高く, 日本膵臓学会膵癌登 録の全国集計ではTS1 の占める割合は $7.9 \%$ であ り, その切除率は $89.6 \%$ であったとされている3 ${ }^{3}$. 管状腺癌の切除例の 5 年生存率は $10.7 \%$ とされ ており,これを腫瘍径別にみると，TS1の 5 年生存率が $31.7 \%$ であり, TS2 以上の例と明ら かに差がみられる. 以上より, 現時点ではCIS のみならず $1 \mathrm{~cm}$ 以下の小さい膵癌の発見を目指 す診療が必要である.

\section{2）小膵癌の描出能}

各種画像による膵癌の腫瘍自体の描出能を, 当センターにて切除し組織学的に再構築した腫
瘍径（pTS）別に検討した。その結果, pTS2 以上の膵癌ではUS 89\%, EUS 94\%, CT 96\%， MRI 94\% であるのに対し, pTS1 ではUS 61\%, EUS $94 \%$, CT $41 \%$, MDCT $67 \%$, MRI 33\% で あった. すなわち, pTS2ではすべての画像診断 で腫瘤の描出が可能であったのに対し, pTS1 ではEUS以外の画像診断では低率であった ${ }^{4)}$.

EUSの膵癌描出能を, 小膵癌に限定して他の 画像診断と比較した報告をまとめて表 1 に示す4). 本邦の多施設研究でも，欧米の報告でも，US, CTの描出能に比較してEUSの有用性を述べてい るものが多い.

\section{3. 膵癌と腫瘤形成性膵炎との鑑別診断}

膵癌の悪性度, 治療法の侵襲性を考慮すると, 鑑別を要する腫瘤形成性膵炎の診断には高い精 度が要求される。一方, 臨床では例え腫瘤の大 部分が炎症性と判断しても，その陰に癌が潜ん でいないかを考慮する必要がある．そのため腫 瘤形成性膵炎の診断成績は切除例からみると必 ずしも良好とは言えない. Thomasら ${ }^{5)}$ は，膵癌 と診断して施行した膵頭十二指腸切除 220 例の うち, $6 \%$ に良性の炎症性病変が含まれていたと 述べている.

腫瘤形成性膵炎の一般的な診断経緯としては, 
表 2. 腫瘤形成性膵炎と膵癌の胆管像の比較一ERCP, EUS一

\begin{tabular}{|c|c|c|c|}
\hline & MFP & PCA & \\
\hline - Clinical findings (pancreas head) & $n=24$ & $n=68$ & \multirow{3}{*}{$\begin{array}{l}\text { N.S. } \\
*\end{array}$} \\
\hline Icterus & $12(50)$ & $46(68)$ & \\
\hline Bile duct stricture & $17(71)$ & $60(88)$ & \\
\hline - ERCP findings ; bile duct stricture & $n=17$ & $n=57$ & \multirow{8}{*}{$\begin{array}{l}* * \\
\text { N.S. } \\
* *\end{array}$} \\
\hline Length $(\mathrm{mm})$ & $24.9+/-13.9$ & $14.4+/-7.6$ & \\
\hline Diameter of upstream bile duct (mm) & $13.6+/-4.9$ & $6.1+/-5.1$ & \\
\hline Irregular V shape & $3(18)$ & $49(86)$ & \\
\hline Smooth stenosis & $14(82)$ & $8(14)$ & \\
\hline Compression & 4 & 6 & \\
\hline Filamentous & 6 & 1 & \\
\hline Cylindrical & 4 & 1 & \\
\hline - EUS findings ; layer structure of proximal bile duct & $n=16$ & $\mathrm{n}=44$ & \multirow{5}{*}{$* *$} \\
\hline Single layer (high) & $6(38)$ & $36(82)$ & \\
\hline Multiple layer & $10(62)$ & $18(18)$ & \\
\hline Two layered（low-high） & 4 & 6 & \\
\hline Three layered (high-low-high) & 6 & 3 & \\
\hline
\end{tabular}

MFP : mass-forming pancreatitis PCA : pancreatic cancer

N.S. : not significant $\quad *: P<0.05 * *: P<0.01 \quad$ ( ) : \%

(文献 7 より改編引用)

はじめに施行されるUSで膵癌が考えられるが, 次に行われるCTやERCPで典型的な膵癌所見と 異なるというdiscrepancyから疑われることが多 い.すなわち, USでは極めて明瞭に捉えられた 腫瘤が, CTでは腫瘤として指摘できず限局性腫 大を示す程度であったり, 通常の膵癌と異なり early phaseから造影効果を示し,また, “capsulelike rim ${ }^{6}$ )" (膵周囲の被膜様構造)がみられれば本 症を示唆する所見となる.このようにUSでは膵 癌との鑑別が困難なことが多く，EUSでもその 情報を越えるものはないとされ，さらにERCP でもそれらの鑑別は難しいとされている，次項 で当センターにおける膵癌と腫瘤形成性膵炎の ERCPとEUS所見の差異について言及する.

\section{1） ERCP像の差異}

\section{（1）胆管像（表 2）}

膵癌と腫瘤形成性膵炎の膵頭部例について比 較すると, 膵癌では $68 \%$ に黄疸がみられたのに 対し, 腫瘤形成性膵炎では $50 \%$ にとどまってい
た. ERCPによる胆管像を比較すると, 膵癌では 88\%に狭窄がみられていたのに対し, 腫瘤形成 性膵炎では $71 \%$ と低かった.さらに胆管狭窄の 形態をみると, 膵癌では $86 \%$ が「不整 $\mathrm{V}$ 字狭窄」 を示したのに対し, 腫瘤形成性膵炎では圧排状, 糸状ないし円筒状などと表現される「平滑狭窄」 で長い狭窄を示す例が多い特徵がみられた ${ }^{7}$. 一 般に慢性膵炎でみられる胆管狭窄は，その範囲 が膵内胆管部に一致することや, 一見, 狭窄が 高度に見えても造影剂の通過は比較的良好なこ とが経験される。このような慢性膵炎に伴う特 有の胆管のしめつけ像が, 腫瘤形成性膵炎での 胆管所見や黄疸発症率の背景となっていると考 えられる。

（2）膵管像（表 3）

ERCPによる膵管像の差異を比較すると, 膵癌 では主膵管の限局性狭窄, 途絶の所見が $97 \%$ に みられるのに対し, 腫瘤形成性膵炎では $1 / 3$ が 典型的な膵癌の狭窄像と異なる膵管像を呈して 
表 3. 睡瘤形成性膵炎と膵癌の膵管像の比較一ERCP, EUS一

\begin{tabular}{|c|c|c|c|}
\hline & MFP & PCA & \\
\hline ERCP findings ; main pancreatic duct & $n=28$ & $n=80$ & \multirow{4}{*}{ 证 } \\
\hline Localized stricture/obstruction & $20(71)$ & $78(97)$ & \\
\hline No-localized stricture/obstruction & $5(18)$ & $2(3)$ & \\
\hline Irregular narrowing & $3(11)$ & O & \\
\hline \multicolumn{4}{|l|}{ Stricture of Wirsung duct } \\
\hline Length (mm) & $21.3+/-5.4$ & $13.6+/-6.6$ & $* *$ \\
\hline Diameter of upstream PD (mm) & $5.2+1-2.2$ & $6.6+1-3.8$ & N.S. \\
\hline EUS findings ; proximal pancreatic duct & $n=25$ & $n=70$ & \multirow{3}{*}{ * $*$} \\
\hline Dilatation & $11(44)$ & $53(76)$ & \\
\hline Non-dilatation & $14(56)$ & $17(24)$ & \\
\hline
\end{tabular}

MFP : mass-forming pancreatitis PCA : pancreatic cancer

N.S. : not significant $\quad * *: P<0.01 \quad$ ( ) : \%

いた. 内訳をみると, 主膵管に限局性狭窄や途 絶がみられなかったのは $18 \%$ であり, 本症の特 徵的超音波像として知られている penetrating duct $\operatorname{sign}^{8}$ の出現頻度, $17 \%$ とょく相関していた. その他, 主膵管の広狭不整, 硬化像等の変化は 顕著であるにも関わらず，これらの所見が腫瘤 部に限局せず，いわゆるび慢性膵管狭細型を呈 した例が $11 \%$ みられた. 腫瘤形成性膵炎では主 膵管狭窄部は長く，その尾側萃管の太さはやや 細い傾向があり, 拡張部への移行が緩やかであ る点は良性所見の特徵と言える ${ }^{7)}$. Lammerら ${ }^{9)}$ も 炎症性腫瘤の主膵管は $56 \%$ で長い狭窄を示して いたと報告している.

\section{（3）膵管と胆管の狭窄所見の不一致}

腫瘤形成性膵炎では膵管と胆管の狭窄像の関 係が, 膵癌の典型像と異なることが経験される. そこで膵管と胆管の狭窄所見の併存に関して比 較してみると, 膵癌では “double duct sign”と 呼ばれるように，膵管と胆管の狭窄所見が共に みられることが $86 \%$ と高率であったが, 腫瘤形 成性膵炎では $52 \%$ と低い結果であった.すなわ ち腫瘤形成性膵炎では膵管狭窄があっても必ず しも胆管に狭窄がみられなかったり，逆に胆管 狭窄がみられても膵癌のような膵管狭窄がみら
れなかったり，狭窄部位が一致しない例が約半 数存在しており, 腫瘤形成性膵炎の特徵の一つ であり, 大きな鑑別のポイントと言える7). Tho-

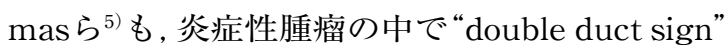
を呈したのは $42 \%$ のみであり,その他は胆管も しくは膵管の単独の狭窄を示したと述べている.

以上のようにERCP所見の読み込みによって， 腫瘤形成性萃炎の鑑別がある程度可能である。 一方，膵管像では鑑別が難しい完全閉塞例が, 腫瘤形成性膵炎でも $25 \%$ にみられることや, 胆 管像については膵癌でも平滑狭窄を示す例が $14 \%$ 存在することなど，読影の際には十分に認識し ていなければならない。

\section{2）EUS像の差異}

EUSによる腫瘤形成性膵炎の正診率は, Rosch ら ${ }^{10)}$ は 46\% であったとし, Palazzoら ${ }^{11)}$ も全ての 腫瘤形成性膵炎がEUSの判定で偽陽性になった として, 膵癌との鑑別診断の困難性を述べてい る.このように腫瘤形成性膵炎に対するUSやEUS の診断能は総じて低いとする報告が多い7).

\section{（1）腫瘤像}

腫瘤形成性膵炎の輪郭と内部構造の 8 因子を 膵癌と比較した結果を表 4 に示す．腫瘤の輪郭 を表す辺縁不整, 境界不明瞭といった所見は膵 


\section{トピックス}

表 4. EUSによる腫瘤形成性膵炎と膵癌の腫瘤像の比較

\begin{tabular}{lccc}
\hline \multicolumn{1}{c}{ EUS findings } & $\begin{array}{c}\text { MFP } \\
n=29\end{array}$ & $\begin{array}{c}\text { PCA } \\
n=77\end{array}$ & $(\%)$ \\
\hline Irregular margin(splotch) & 97 & 83 & N.S. \\
Unclear margin & 48 & 49 & N.S. \\
Penetrating duct sign & 17 & 6 & N.S. \\
Ductal structure & 34 & 39 & N.S. \\
Strong echo/comet sign & 90 & 22 & $* *$ \\
High echo spot & 79 & 44 & $* *$ \\
Echo free space & 69 & 29 & $* *$ \\
Heterogenous echo & 76 & 52 & $*$ \\
\hline MFP : mass-forming pancreatitis & PCA : pancreatic cancer \\
N.S. : not significant & $*$ : $P<0.05 * *:$ P $<0.01$ &
\end{tabular}

（文献 7 より引用）

癌と差がみられず，鑑別に用いるのは危険であ ることがわかる．腫瘤形成性膵炎で有意に高い 頻度でみられたEUS所見は, 内部構造に関して $\lceil$ strong echo/comet sign」,「無エコー域：echo free spaceの散在」,「高エコー巣 : hyperechoic foci」 $(P<0.01)$ および「内部不均一：heterogeneity」 $(P<0.05)$ の因子であった.「strong echo/ comet sign」は腫瘤形成性膵炎の $90 \%$ と高頻度 にみられ, 統計学的有意差がみられたが, 膵癌 の $22 \%$ にみられることも認識しておかなければ ならない. echo free spaceは癌にみられる中心壊 死とは異なり, 辺縁部にも散在してみられてい た. 腫瘤形成性膵炎における「penetrating duct sign」の出現率は報告によって，10〜 70\% とば らつきがみられる．著者らの検討では出現率は $17 \%$ であり, 前述のERCP所見に呼応していた (表 3) ${ }^{7}$.

（2）膵管像（表 3）

EUSで観察すると, 膵癌では腫瘤の尾側膵管 の拡張が $76 \%$ にみられるのに対し, 腫瘤形成性 膵炎では拡張を伴わない例が $56 \%$ 存在した.こ れは明らかに膵癌の典型像とは異なっており，

これまでの報告と一致する ${ }^{7)}$.このようなEUS 像の背景としては, ERCP所見で主膵管の限局性 狭窄や閉塞を示さない例と膵管狭細型を呈する
例を合わせると約 $1 / 3$ を占めたこと, また, 狭 窄例に関しては尾側膵管の拡張径が膵癌例より 細い傾向を示していたことなどが考えられた.

（3）胆管像（表 2)

胆管壁構造を, ドレナージ前の層構造の出現 率について比較した，膵頭部癌では胆管壁は一 層の高エコーとして描出されることが多い $(82 \%)$ のに対し，腫瘤形成性膵炎では層構造を有する 胆管壁肥厚が $62 \%$ にみられた. 前述のとおり腫 瘤形成性膵炎では胆管狭窄, 黄疸の発症率は共 に低いが，胆管壁は層構造を呈し易いことにな る。腫瘤形成性膵炎では膵癌にみられる進行性 の胆管狭窄とは異なり, 膵から胆管側への炎症 の波及や可逆性狭窄に伴う胆管自体の炎症, 浮 腫などがこのような超音波像を惹起しているも のと推測される，胆管壁の組織像が検討できた 例では，いずれも胆管全層におよぶ炎症細胞浸 潤と胆管漿膜下層から線維筋層にかけて膵から 連続する線維化が壁肥厚の原因となっていた ${ }^{7}$.

\section{4. 膵癌と限局性AIPの鑑別}

\section{1）腫瘤形成性膵炎と限局性AIP}

膵癌の診断もしくは疑って手術した症例のう ち，術後の検索で良性であった頻度は 6 23\% 


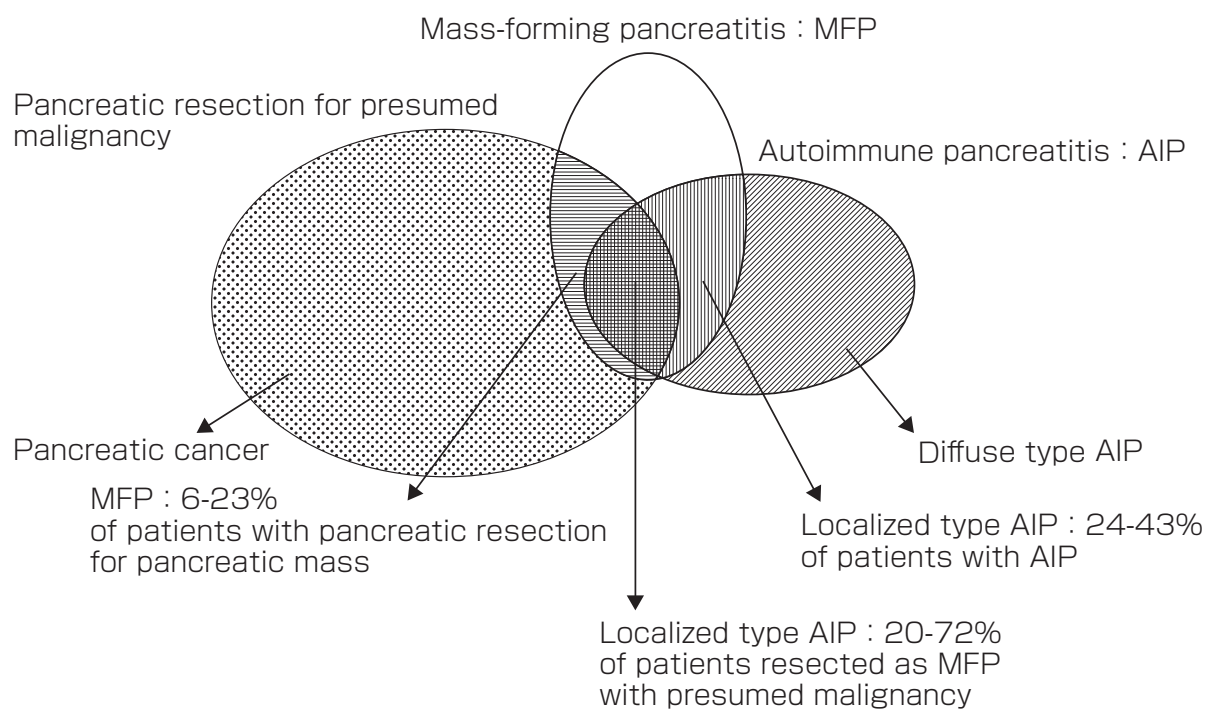

（文献12より改編引用）

図 1. 膵癌と術前診断した例と腫瘤形成性膵炎, 自己免疫性膵炎との関係

と様々な報告がみられる ${ }^{12)}$. その多くはAIPの概 念が広く認識される前の報告で，これらは膵癌 との鑑別が困難なAIPを含む腫瘤形成型膵炎の頻 度と考えられる。当センターで膵癌を否定でき ずに切除した腫瘤形成性膵炎は 11 名で,このう ち組織学的にAIPと診断したのは 8 名, $72 \%$ で あった ${ }^{12,13)}$. Takaseら ${ }^{14)}$ は切除例の病理学的検討 で腫瘤形成性膵炎の中の $20 \%$ がAIPであったと 述べている.このようにAIPの中で限局性に腫瘤 を形成する頻度は当センターでは 26 名中 10 名, $38 \%$ であり, その他の報告では 24 43\% とされ ている12) (図 1).

AIPの組織像はKawaguchiら ${ }^{15)}$ によって初めて 示されたlymphoplasmacytic sclerosing pancreatitis (LPSP) が基本となっている（症例 1 , 図 2) ${ }^{16)}$. AIPの診断基準は 2006 年に日本膵臓学 会から改定版が示され ${ }^{17)}$, 形態的, 病理学的特徵 の他, 血清IgG4 ${ }^{18)}$ の上昇により, 本症と診断する ことが可能である.

限局性AIP以外の腫瘤形成の機序は同じ成因論 では説明できないが，急性膵炎ないし慢性膵炎 を背景にpseudocystを生じ，その縮小，吸収， 器質化の段階で腫瘤と認識される例が経験され る. 比較的太いレベルの膵管分枝の閉塞, 局所 的な循環不全, 血管病変の介在などが原因とし て推察される.須田ら ${ }^{19)}$ は組織学的検討から, 慢 性膵炎の経過中, 蛋白栓, 膵石などにより主膵 管に狭窄や炎症が惹起され, 程度に応じて出血, 壊死, 膿瘍化, 囊胞化が生じ, その修復機転と してactiveな肉芽組織や線維化が出現し腫瘤を形 成する機序を考察している。

\section{2）AIPの超音波像の特徵}

AIPの特徵的超音波所見を表 5 に示す. 膵はび 漫性腫大を示す “sausage-like”もしくは限局性 に腫大した低エコーとなる.時にcomet-like echoes, hyperechoic fociが散在する. CTで典型的 とされる“capsule-like rim”は特に限局型におい てはUSでこれに相当する所見が描出されること は少ない. EUSでも同様に膵癌との鑑別におい てCT, MRI, ERCPなどの画像情報を凌駕する ことは少ない.

AIPとアルコール性慢性膵炎との大きな違い 


\section{トピックス}
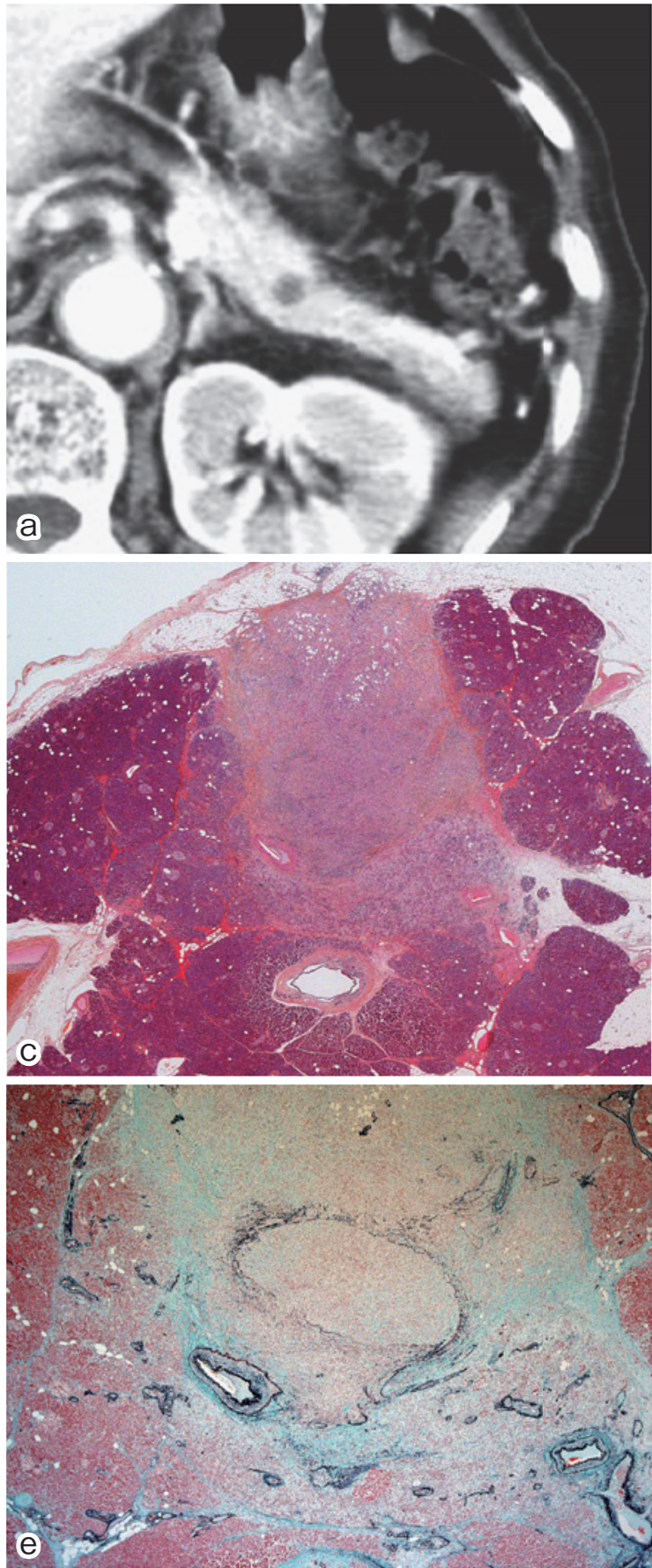
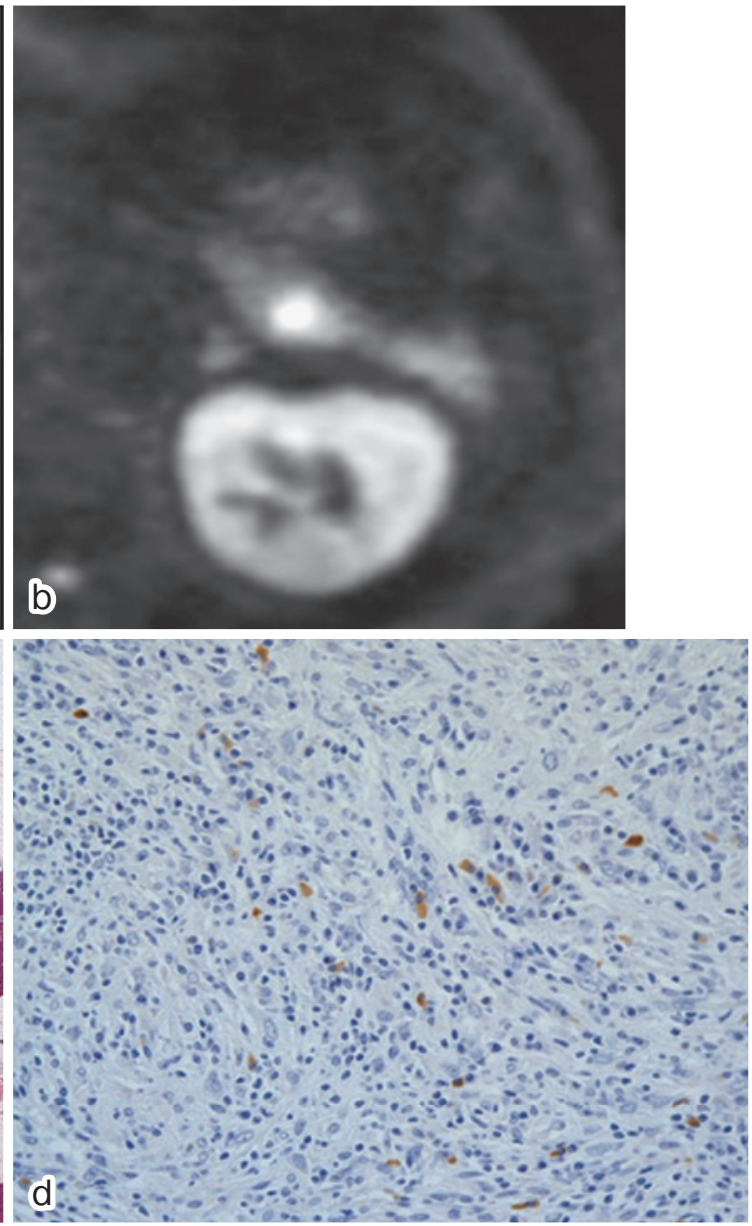

図 2. 症例 174 歳, 男性. 限局性自己免疫性膵炎 血清IgG4 值 : $64 \mathrm{mg} / \mathrm{dl}$

造影CTの動脈相ではわずかに造影効果を有する小腫 瘤が脺体尾部移行部にみられる (a).MRIの拡散強調 画像では同部位に顕著なhigh signalが検出される (b). 腫瘤は $9 \times 8 \mathrm{~mm}$ で内部は線維化を伴う多数の リンパ球と形質細胞の浸潤がみられる（H\&E staining $\times 2.5) （ c)$. また, IgG4 陽性の形質細胞が豊富 に観察される（IgG4 staining $\times 40 ）(d)$. 腫瘤内に は閉塞性静脈炎が確認されlymphoplasmacytic sclerosing pancreatitisと診断できる (ElasticaMasson staining $\times 5)(e) . \quad$ (文献 16 より引用)
は, 石灰化や囊胞形成が少ない点である. AIP は通常の慢性膵炎のような非可逆的で進行性の 病態とは異なると考えられている。しかし, 報
告されるAIPの症例数の増加に伴い, 石灰化や囊 胞形成の合併例がみられるようになってきた。 Nakazawaら ${ }^{20)}$ は37名のAIPのうち3名で石灰化, 


\section{表 5. 自己免疫性膵炎の超音波所見}

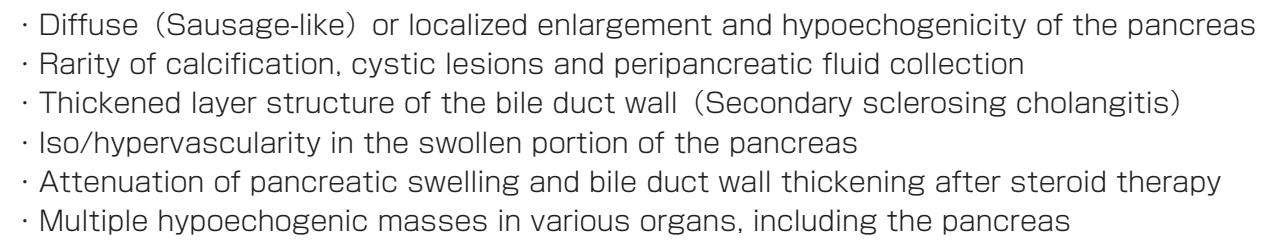

(文献 12 より引用)
2 名で囊胞形成がみられたと述べている.これら の頻度は通常の慢性萃炎ほど顕著ではないが, 超音波でcomet-like echoes, hyperechoic foci などがみられることからも十分起こり得ること と推察される. AIPは症状に乏しいが, 病態的に は再燃を繰り返していることも考えられ，慢性 膵炎への移行には注意を要する.

\section{3) EUS-FNA}

膵癌と腫瘤形成性膵炎の鑑別にはEUS-FNA (EUS-guided fine-needle aspiration) が有用とさ れ, Wiersemaら ${ }^{21)}$ は正診率が 85〜96\% と高いこ とを報告している.さらにEUS-FNAによって得 られた標本の免疫染色による顕著なIgG4 陽性形 質細胞 ${ }^{18)}$ の証明や, 組織診による閉塞性静脈炎 ${ }^{12,14)}$ の存在によりAIPの確定診断が可能となる.

当センターではEUS-FNAによる細胞診におい て, 免疫染色も可能なcell block法の有用性を従 来のsmear法と比較するため, 膵腫瘤の 33 名を 対象に，同じ穿刺で得られた検体をもとにRCT (randomized controlled trial) を行った。 その結 果, 通常型膵癌に対するそれぞれの感度, 正診 率はcell block法では 92.0\%, 93.9\% とsmear法の $60.0 \%, 60.6 \%$ よりも高い結果が得られた（ $P=$ $0.02)(P=0.003)^{22)}$.

Mizunoら ${ }^{23)}$ はAIPが疑われた 14 名を対象に EUS-guided trucut biopsy（TCB）の診断能を検 討している。 その結果, EUS-FNAとEUS-TCB はともに膵癌を否定することが可能で, EUSTCBではAIPの 8 名をすべてLPSP と診断可能で あり, 今後, 非典型的なAIPの診断の手助けにな
ると述べている. しかし, EUS-FNAでは消化管 の生検同様, 常にサンプリングエラーのリスク があり，癌を否定する方法論ではないことを認 識する必要がある.

画像診断から切除適応と判断した例にも FNA を施行すべきか否かは，播種の危険に対する安 全性が確保されない限り結論がだせない.また， 血流の豊富なP-NETなどはdrainage veinも太く， FNAによる腫瘍内の頻回なstrokeの血行性転移 に対する安全性も示される必要がある。根治可 能な小膵癌や悪性度が低い腫瘍ほど, 画像診断 を駆使して穿刺によるriskを回避する必要があ る.

\section{4）ERCP下膵液細胞診}

われわれは膵癌の腫瘍径による主膵管上皮内 進展の特徴と, 膵液細胞診の関連を明らかにす るために, 切除膵癌のpTS1, 20 名と, 対照とし てpTS2 以上の 40 名を比較検討した ${ }^{24)}$. その結 果, 主萃管内進展はpTS1 の 45\% にみられたの に対して, 対照群では $13 \%$ と低く, 平均進展長 も pTS1 で $11.8 \mathrm{~mm}$ と対照群の $7.2 \mathrm{~mm}$ より長かっ た。膵液細胞診の陽性率はpTS1 群で $70 \%$ と， 対照群の $50 \%$ より高い結果であった. 主膵管内 進展の頻度と共に細胞診での陽性率がpTS1 で高 いことから, 小膵癌に対する経乳頭的アプロー チによる診断の可能性が示唆された.

また，鑑別診断のための膵液細胞診を，腫瘤 形成性膵炎 9 名と膵癌 11 名に対して行い, 感度, 特異度を検討した，膵液細胞診では，腫瘤形成 性膵炎をclass IV, Vと判定した例はみられなかっ 
表 6. 睡瘤形成性膵炎に対する造影USの報告例

\begin{tabular}{|c|c|c|c|c|c|c|c|c|}
\hline \multirow{3}{*}{$\begin{array}{l}\text { Author } \\
\text { Koito } \\
\text { Oshikawa }\end{array}$} & \multirow{2}{*}{$\begin{array}{l}\text { Year } \\
1997\end{array}$} & \multirow{2}{*}{$\begin{array}{c}\begin{array}{c}\text { No. of } \\
\text { patients }\end{array} \\
20\end{array}$} & \multirow{2}{*}{$\begin{array}{l}\text { Contrast agent } \\
\mathrm{CO}_{2} \text { microbubble }\end{array}$} & \multirow[t]{2}{*}{ Vascular image } & \multicolumn{2}{|c|}{$\begin{array}{l}\text { Perfusion image } \\
\text { Enhancement }\end{array}$} & \multirow{2}{*}{$\begin{array}{c}\begin{array}{c}\text { Sensi- } \\
\text { tivity }\end{array} \\
95\end{array}$} & \multirow{2}{*}{$\begin{array}{l}\text { Sensitivity } \\
\text { of Enhanced } \\
\text { CT (\%) } \\
73\end{array}$} \\
\hline & & & & & Isovascular & 95 & & \\
\hline & 2002 & 4 & Levovist & & Slight & 50 & & \\
\hline & & & & & Moderate & 50 & & \\
\hline \multirow{2}{*}{ Ozawa } & 2002 & 3 & Levovist & & Mild & 33 & & \\
\hline & & & & & Pronounced & 77 & & \\
\hline Rickes & 2002 & 41 & Levovist & & & & 85 & \\
\hline Kitano & 2003 & 7 & Levovist & Isovascular 100 & Isoperfusion & 100 & 95 & 89 \\
\hline Sofuni & 2005 & 5 & Levovist & Isovascular 80 & Isoperfusion & 100 & 87 & 79 \\
\hline
\end{tabular}

(文献 12 より引用)

たが, class IIIの判定が $33 \%$ みられた. 一方, 膵 癌ではclass I, II とした疑陰性例が $36 \%$ みられた。 class IIIの取り扱いが問題になるが, 腫瘤形成性 膵炎からみた場合, 細胞診で癌が疑われては診 断に有用とは言えないため, class I, IIのみを正 診とすると, 感度は $67 \%$, 特異度は $40 \%$ と低い 結果であった.

膵液細胞診においても, 免疫染色が可能なcell block法と従来のsmear法の診断精度を比較する ため，膵疾患の 170 名を対象にRCTを行った. その結果, 細胞診上borderline malignancy と判定 される率がsmear法では $27.1 \%$ であったのに対 し, cell block法では 3.5\% まで低下していた $(P<0.001)$. また, 通常型膵癌に対する感度はcell block法, $88.9 \%$, smear法, $42.9 \%$ と有意にcell block法が高い結果であった $(P=0.048)^{25)}$.

\section{5. topics}

\section{1）血流の多寡からみた膵癌と限局性AIPの鑑} 別

AIPの腫大部の血流は, CTやUSの造影による 評価では, 炎症所見を反映してisovascularないし はhypervascularとして描出され, 一般に早期相 でhypovascularを呈する膵癌との鑑別診断に役 立つとされている ${ }^{12)}$. 超音波造影剤はcarbon di- oxide microbubblesから始まり Levovist ${ }^{\mathbb{R}}$ を経て, 現在はSonazoid ${ }^{\circledR}$ (GE Healthcare AG, Oslo, Norway）が使用されている.

腫瘤形成性膵炎に対する造影USの評価を表 6 に示す ${ }^{12)}$. 膵癌の造影所見をhypovascularないし はhypoperfusionとした場合の正診率は, 造影US で 85〜 87\% であり, CTの 73〜 89\% と同等かそ れ以上と報告されている。 また，このような血 流評価はsteroid治療後の効果判定にも有用性が 期待される.

AIPの組織所見の特徵として閉塞性静脈炎の存 在が挙げられ，リンパ球や形質細胞によって大 小様々な静脈の閉塞が確認されるが, 動脈系へ の影響はほとんどみられない12,14) $\left(\right.$ 症例 1 , 図 2) ${ }^{16)}$. 一方, 膵癌の腫瘤部は動静脈を問わず浸潤がみ られ，線維化の誘導も顕著である。このような 血管浸潤の異なる組織像を背景に，われわれは 新たな血流評価を超音波造影剂と color-Doppler EUSを組み合わせて試みている.

これまでのcolor-Doppler法は解像度が低く, また, 造影剤の使用はblooming artifactを惹起す ることから両者の組み合わせの相性は悪いもの と考えられてきた。近年, directional $\mathrm{eFLOW}^{\circledR}$ (Prosound $\alpha 10$, Aloca Co., Tokyo, Japan) が開発 され, Doppler法にもかかわらず, 超音波送受信 の広帯域化が可能になり, 空間分解能および時 

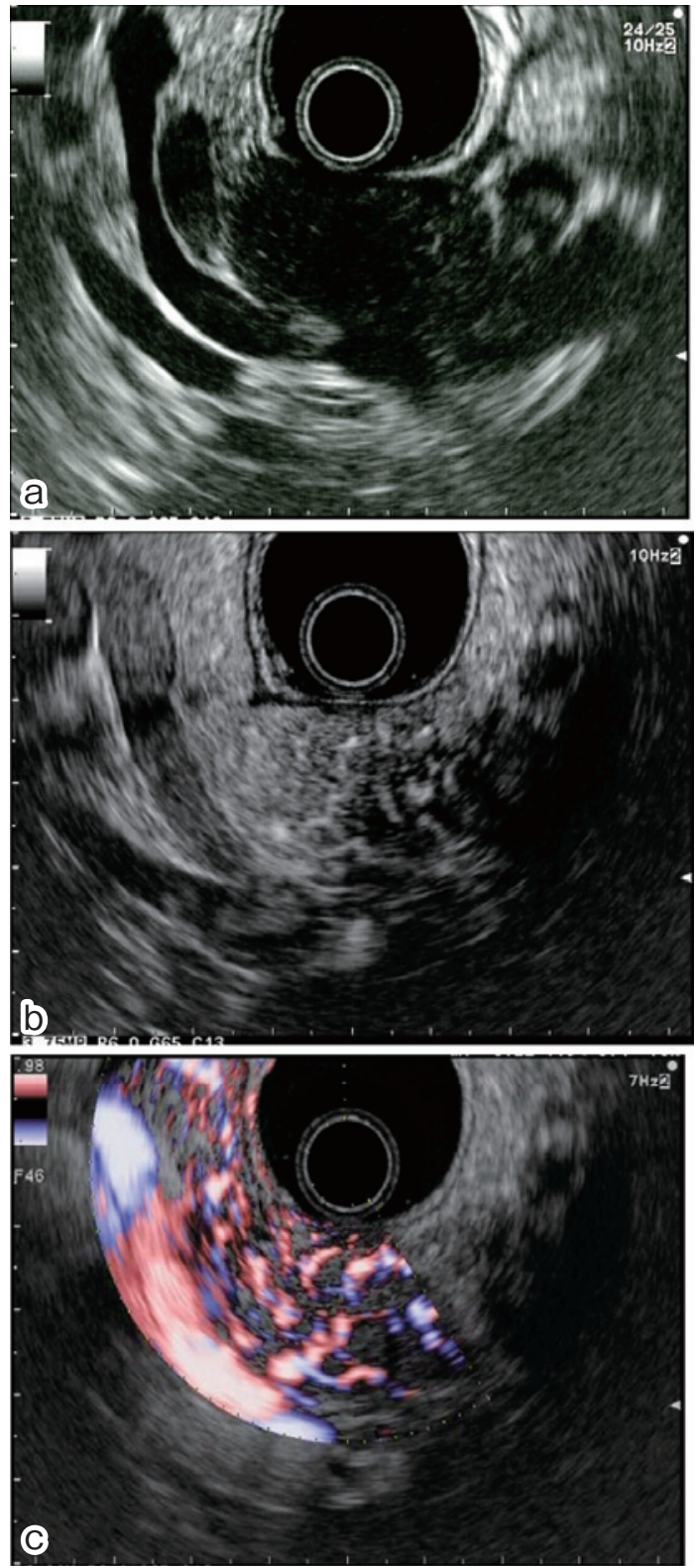

図 3. 症例 252 歳, 男性. 限局性自己免疫性 膵炎 血清IgG4 值 : $146 \mathrm{mg} / \mathrm{dl}$

EUSでは膵尾部に低エコ一腫瘤を認める (a)

Sonazoid ${ }^{\circledR}$ (0.85 ml/body) による造影EUSを tissue harmonic modeで観察すると, 15 秒 後にはperfusionされるhypervascularな腫瘤と して描出される(b). 腫瘤は20 秒後にはhomogenousにperfusionされ，30 秒後にEFLOW ${ }^{\circledR}$ modeで観察すると腫瘤内の豊富な血管構築像が 描出された（c).

(文献 12 より引用)
間分解能が改善された。さらに, 低流速の検出 力も向上し, かつblooming artifactも抑えられる ようになった。これまでは造影剤を使用する時 に組織からのharmonic成分を可能な限り拾わず, 気泡の容積歪み, 共振を描出する contrast harmonic imagingが用いられていた，そのため画像 は若干狭帯域となって粗く, 画質が低下する傾 向がみられた，著者らはEUSを用いて，背景の 画質を低下させないためにtissue harmonicのま まで, eFLOW ${ }^{\circledR}$ とSonazoid ${ }^{\circledR}$ とを組み合わせて使 用する contrast-enhanced color-Doppler EUS (CC-EUS)によってAIPの血管構築の評価を行っ た.

対象はAIP14 名であり, 膵癌 14 名を対照とし て, perfusion imagesとeFLOWによる血管構築 像を比較した。その結果, perfusion imagingで homogenous patternを示したのがAIPでは 79\% であり, 膵癌では $43 \%$ と低かったが両群間で差 はなかった $(P=0.05)$.すなわち, これまでは膵 癌の腫瘤部は造影剤がperfusion し難いことから hypovascularと判定される報告が多かったが, Sonazoid ${ }^{\circledR}$ とEUSによるtissue harmonicでの判 定では, 脺癌でも半数近くにhomogenous perfusionがみられた。つぎにheterogenous pattern を呈した例を分析すると，まだらにlow echoic areasを呈する例はAIPでは 7\% であるのに対し， 膵癌では $43 \%$ と多い結果であった $(P=0.04)$. Sonazoid ${ }^{\circledR}$ がperfusionしてからeFLOWを用いて 血管構築像を評価すると, AIPの 86\% にfine network vascular patternがみられたのに対し(症例 2 , 図 3 ${ }^{15)}$, 膵癌では全例にこのような所見はみ られず, 5 本以下のfew feeder vesselsが確認され るのみであった. 以上の結果からSonazoid ${ }^{\circledR}$ を用 いたeFLOW ${ }^{\circledR}$ color modeによるEUSは, 腫瘤の 血管構築の描出に優れ, AIP と膵癌の鑑別診断に 有用と考えられる。 


\section{まとめ}

膵癌の多くはMDCTによる進展度診断で切除 適応が判定される. 切除不能で化学療法の適応 がある膵癌や質的診断が困難な例にはEUS-FNA による組織学的診断が有用である. 膵癌の鑑別 診断では, 精度の高いERCP, EUSからみた腫瘤 像, 胆管像, 膵管像の疾患による差異を認識し ておくことが重要である. 小膵癌や上皮内癌の 診断にはERCP関連手技が必要である. また, 造 影CTの他に, 造影USや造影EUSによる血流評価 が鑑別診断に有用である。

著者のCOI (conflicts of interest) 開示: 本論文発表内容に 関連して特に申告なし

\section{文献}

1) 日本膵臟学会膫癌診療ガイドライン改定委員会: 科学的 根拠に基づく 膵癌診療ガイドライン 2009 年版.

2) 小林 剛, 他: IPMN由来膵癌とIPMN併存膵癌. 肝胆膵 $61: 445-457,2010$.

3) 日本膵臓学会膵癌登録委員会 : 日本膵臓学会膵癌登録 20 年間の総括. 膵臟 $18: 97-169,2003$.

4）小林 剛, 他 : pTS1 膵癌の診断手順とEUSの役割. 胆 と膵 $26: 529-537,2005$.

5) Thomas $\mathrm{M}$, et al: Incidence and clinical findings of benign, inflammatory disease in patients resected for presumed pancreatic head cancer. Gastrointestinal Endoscopy 46 : 17-423, 1997.

6) Irie $\mathrm{H}$, et al: Autoimmune pancreatitis: $\mathrm{CT}$ and $\mathrm{MR}$ characteristics. AJR Am J Roentgenol 170 : 1323-1327, 1998.

7）小林 剛, 他：ERCPとEUSによる腫瘤形成性膵炎の鑑 別診断. 胆と膵 $23: 643-652,2002$.

8）木本英三, 他 : 慢性膵炎と膵癌の鑑別診断. 腹部画像診 断 $4: 243-251,1984$.

9) Lammer J, et al: Pseudotumorous pancreatitis. Gastrointest Radiol 10 : 59-67, 1985.

10) Rosch $\mathrm{T}$, et al: Endoscopic ultrasound in pancreatic tumor diagnosis. Gastrointest Endosc 37 : 347-352, 1991.

11) Palazzo L, et al: Endoscopic ultrasonography in the diagnosis and staging of pancreatic adenocarcinoma. Endo- scopy $25: 143-150,1993$

12) Kobayashi G, et al : Autoimmune pancreatitis : with special reference to a localized variant. J Med Ultrasonics 35 : 41-50, 2008.

13) Kobayashi G, et al : Lymphoplasmacytic sclerosing pancreatitis forming a localized mass : a variant form of autoimmune pancreatitis. J Gastroenterol 42 : 650-656, 2007.

14) Takase M, Suda $K$ : Histopathological study on mechanism and background of tumor-forming pancreatitis. Pathol Int 51 : 349-354, 2001.

15) Kawaguchi K, et al: Lymphoplasmacytic sclerosing pancreatitis with cholangitis : a variant of primary sclerosing cholangitis extensively involving pancreas. Hum Pathol $22: 387-395,1991$.

16) Koshita $S$, et al: Localized autoimmune pancreatitis, 9 $\mathrm{mm}$ in size, without strictures of the main pancreatic duct. Gastrointest Endosc 2011.

17) Members of the Criteria Committee for Autoimmune Pancreatitis of the Japan Pancreas Society : Clinical diagnostic criteria of autoimmune pancreatitis 2006 by the Japan Pancreas Society. J Jpn Pancreas (Suizou) 21 : 397, 2006.

18) Hamano H, et al: High serum IgG4 concentrations in patients with sclerosing pancreatitis. N Engl J Med 344 : 732-738, 2001.

19）須田耕一, 他 : 腫瘤形成性膵炎の病理. 腹部画像診断 $15: 547-555,1995$.

20) Nakazawa $T$, et al: Difficulty in diagnosing autoimmune pancreatitis by imaging findings. Gastrointest Endosc 65: 99-108, 2007.

21) Wiersema MJ, et al: Endosonography-guided fine-needle aspiration biopsy : diagnostic accuracy and complication assessment. Gastroenterology 112 : 1087-1095, 1997.

22) Noda $Y$, et al : Prospective randomized controlled study comparing cell block method and conventional smear method for pancreatic juice cytology. Dig Endosc 2011.

23) Mizuno N:Histological diagnosis of autoimmune pancreatitis using EUS-guided trucut biopsy : a comparison study with EUS-FNA. J Gastroenterol 44 : 742-750, 2009.

24) Takasawa $\mathrm{O}$, et al : Clinicopathological study on the intraductal spread of small pancreatic cancer. J Gastroenterol 42: 957-961, 2007.

25) Noda $Y$, et al:Diagnostic efficacy of the cell block method in comparison with smear cytology of tissue samples obtained by endoscopic ultrasound-guided fineneedle aspiration. J Gastroenterol 45 : 868-875, 2010. 